NBER WORKING PAPER SERIES

\title{
CREDIT MARKET IMPERFECTIONS IN MIDDLE INCOME COUNTRIES
}

\author{
Aaron Tornell \\ Frank Westermann \\ Working Paper 9737 \\ http://www.nber.org/papers/w9737
}

\section{NATIONAL BUREAU OF ECONOMIC RESEARCH 1050 Massachusetts Avenue Cambridge, MA 02138}

May 2003

This paper was prepared for the conference "Financial Market Development in Latin America," at the Center for Research on Economic Development and Policy Reform at Stanford University. The views expressed herein are those of the authors and not necessarily those of the National Bureau of Economic Research.

(C2003 by Aaron Tornell and Frank Westermann. All rights reserved. Short sections of text not to exceed two paragraphs, may be quoted without explicit permission provided that full credit including (C) notice, is given to the source. 
Credit Market Imperfections in Middle Income Countries

Aaron Tornell and Frank Westermann

NBER Working Paper No. 9737

May 2003

JEL No. E32, F32, G15, O16

\section{ABSTRACT}

In this paper we document three credit market imperfections prevalent in middle income countries that can help to explain boom-bust cycles, as well as other macroeconomic patterns observed at higher frequencies across these countries. These imperfections are: the existence of financing constraints that affect mainly the nontradables sector, currency mismatch and guarantees that cover lenders against systemic crises. In MICs T-sector firms have access to international capital markets, while most $\mathrm{N}$-firms are bank-dependent and are financially constrained. Systemic guarantees generate incentives for borrowers to take on insolvency risk by denominating debt in foreign currency. This currency mismatch makes movements in the real exchange rate --the relative price between $\mathrm{N}$ and $\mathrm{T}$ goods-- the driving element in the amplification of shocks.

Aaron Tornell

Department of Economics

UCLA, 405 Hilgard Avenue

Bunche Hall 8283

Los Angeles, CA 90095

and NBER

tornell@econ.ucla.edu
Frank Westermann

CESifo

University of Munich and ifo Institute

Schackstr. 4

80539 Munich

Germany

westermann@cesifo.de 


\section{Introduction}

In recent decades many middle income countries (MICs) have liberalized their financial markets. Financial liberalization has typically been followed by lending booms during which credit grows unusually fast. Some of these booms have been punctuated by twin currency and banking crises that are followed by a protracted credit crunch.

In this paper we document three credit market imperfections prevalent in MICs that can explain these boom-bust cycles as well as other macroeconomic patterns observed at higher frequencies across MICs. These imperfections are the existence of borrowing constraints (the effects of which differ across sectors), currency mismatch and systemic bailout guarantees.

Prior to twin crises the typical MIC experiences a real exchange rate appreciation and a lending boom during which the ratio of credit-to-GDP grows unusually fast. In the aftermath of twin crises there is typically a short-lived recession and a protracted credit crunch that persists long after aggregate growth has resumed. The credit crunch hits mainly small and nontradables (N) firms. In fact, nontradables production declines relative to the output of the tradables $(\mathrm{T})$ sector for several years after the crisis, and the credit-to-GDP ratio falls. This asymmetric sectorial pattern is also observed before a crisis as the $\mathrm{N}$-sector grows faster than the T-sector.

In contrast to the crises of earlier decades, large fiscal deficits have not taken center stage in the new boom-bust cycles. Furthermore, investment is the component of GDP that experiences by far the largest swings over the cycle, and, at the other extreme, consumption varies the least. 
These comovements between credit, the N-to-T output ratio and the real exchange rate also arise at higher frequencies, even if we do not condition on the occurrence of crises. Panel regressions reveal that credit growth is positively correlated with the ratio of N-to-T output, with changes in the real exchange rate, and with investment growth. However, credit growth is not significantly correlated with either aggregate GDP growth or consumption.

These comovements and the boom-bust cycle are not observed in countries with developed financial markets. They appear to be the same across MICs, in spite of different exchange rate regimes. These facts indicate that the mechanisms at work are not dependent on particular features of the exchange rate regime, but rather on other institutional characteristics of MICs. It has been argued in the literature that they are generated by the interaction of three characteristics of financing typical of MICs. First, there is a pronounced asymmetry in size and financing opportunities across tradables $(\mathrm{T})$ and non-tradables $(\mathrm{N})$ sectors. While T-sector firms tend to be large and have access to world capital markets, N-sector firms are smaller on average, are bank-dependent and face borrowing constraints. ${ }^{1}$

Second, in MICs a substantial amount of N-sector debt is dollar denominated, while the income streams that service those debts are in domestic currency. Since domestic banks are heavily exposed to the N-sector, the degree of currency mismatch is significant. Even when the banks' balance sheets are equilibrated, banks face a de facto currency mismatch because they lend primarily to the N-sector. Thus, they face insolvency risk.

Third, creditors are covered, either explicitly or implicitly, by systemic bailout guaran-

\footnotetext{
${ }^{1}$ In MICs T-sector firms have easy access to external finance because they can either pledge export receivables as collateral, or can get guarantees from closely linked firms.
} 
tees. It is expected that if a critical mass of debtors risks insolvency, the government will implement policies to ensure that creditors get repaid (at least in part) and thus avoid an economic meltdown. These policies may come in the form of an easing of monetary policy, the maintenance of an exchange rate peg, or the handing out of checks.

This paper is structured as follows. In Section 2 we document the credit market imperfections. In Section 3 we characterize the boom-bust cycle and the comovements alluded to above. In Section 4 we describe the mechanism that links the credit market imperfections to the stylized facts. Finally in Section 5 we present the conclusions.

\section{Credit Market Imperfections}

Here we present evidence on the three key credit market imperfections that prevail in MICs: asymmetric financing opportunities, currency mismatch and systemic guarantees.

We classify as MICs all countries that satisfy the following four conditions: they have a per-capita income between $\$ 1,000$ and $\$ 18,000$; in addition to banks, the stock market is a viable source of finance; they have a population greater than 1 million people; the country has not engaged in war or civil war during the sample period. Thirty seven countries satisfy these conditions. We also consider Sweden and Finland, whose per capita incomes are greater than $\$ 18,000$ but have experienced often studied twin crises. Thus, our sample consists of 39 countries. $^{2}$ We consider the period between 1980 and 1999.

\footnotetext{
${ }^{2}$ Argentina, Brazil, Chile, Colombia, Croatia, Czech Republic, Ecuador, Egypt, Estonia, Finland, Greece, Hungary, Indonesia, Ireland, Israel, Jordan, Korea, Latvia, Lithuania, Malaysia, Mexico, Morocco, New Zealand, Peru, Philippines, Poland, Portugal, Russia, Saudi Arabia, Slovak Republic, Slovenia, South Africa, Spain, Sweden, Thailand, Tunisia, Turkey, Uruguay, Venezuela.
} 
Table 2.1: Sectorial and Size Distributions of Firms

\begin{tabular}{ccc}
\hline \hline & N-Sector & T-Sector \\
\cline { 2 - 3 } Small & $68 \%$ & $32 \%$ \\
Large & $33 \%$ & $67 \%$ \\
\hline \hline
\end{tabular}

Source: World Business Environment Survey (WBES), 2001.

Note: "small" corresponds to firms with up to 200 employees.

\subsection{Asymmetric Financing Opportunities}

In order to investigate whether there is a significant difference between firms in the T-sector and those in the N-sector, we use firm level data from a panel of 3877 firms of the World Business Economic Survey of the World Bank (WBES, 2001). This survey covers 27 out of our sample of $39 \mathrm{MICs}$, and it classifies firms according to their size and, among other things, whether or not they export. ${ }^{3}$ Since the share of T-output in the group of export firms is greater than that of non-export firms, we identify exporters with T-sector firms and non-exporters with N-sector firms.

The first question we ask is whether firms in the T-sector tend to be larger than those in the N-sector. The answer is positive. Table 2.1 shows that, across the 27 countries in the WBES survey, a majority (68 percent) of small and medium firms belongs to the N-sector, while a majority (67 percent) of large firms belongs to the T-sector. This fact holds true when looking at the matrices of individual countries. Table 2.2 shows that the distribution

\footnotetext{
${ }^{3}$ Argentina, Brazil, Chile, Czech Republic, Ecuador, Egypt, Estonia, Hungary, Indonesia, Lithuania, Mexico, Malaysia, Peru, Philippines, Poland, Portugal, Russia, Slovakia, Slovenia, South Africa, Spain, Sweden, Thailand, Turkey, Tunisia, Uruguay and Venezuela. Schiffer and Weder (2001) describe in detail this data base. It is available from the World Bank at: http://www.worldbank.org/beext/resources/assesswbessurvey-alt.htm
} 
Table 2.2: Sectorial and Size Distributions for Individual Countries Argentina:

\begin{tabular}{ccc}
\hline & N-Sector & T-Sector \\
\cline { 2 - 3 } Small & $74 \%$ & $26 \%$ \\
Large & $67 \%$ & $33 \%$ \\
\hline \hline
\end{tabular}

Brazil:

\begin{tabular}{ccc}
\hline \hline & N-Sector & T-Sector \\
\cline { 2 - 3 } Small & $73 \%$ & $27 \%$ \\
Large & $60 \%$ & $40 \%$ \\
\hline \hline
\end{tabular}

Chile:

\begin{tabular}{ccc}
\hline \hline & N-Sector & T-Sector \\
\cline { 2 - 3 } Small & $63 \%$ & $37 \%$ \\
Large & $48 \%$ & $52 \%$ \\
\hline \hline
\end{tabular}

Indonesia:

\begin{tabular}{ccc}
\hline \hline & N-Sector & T-Sector \\
\cline { 2 - 3 } Small & $82 \%$ & $18 \%$ \\
Large & $54 \%$ & $46 \%$ \\
\hline \hline
\end{tabular}

Mexico:

\begin{tabular}{ccc}
\hline \hline & N-Sector & T-Sector \\
\cline { 2 - 3 } Small & $68 \%$ & $32 \%$ \\
Large & $38 \%$ & $62 \%$ \\
\hline \hline & & \\
& Malaysia: & \\
\hline \hline & & T-Sector \\
Small & N-Sector & $35 \%$ \\
\cline { 2 - 3 } Large & $65 \%$ & $60 \%$ \\
\hline \hline
\end{tabular}

Philippines:

\begin{tabular}{ccc}
\hline \hline & N-Sector & T-Sector \\
\cline { 2 - 3 } Small & $73 \%$ & $27 \%$ \\
Large & $48 \%$ & $52 \%$ \\
\hline \hline
\end{tabular}

Thailand:

\begin{tabular}{ccc}
\hline \hline & N-Sector & T-Sector \\
\cline { 2 - 3 } Small & $61 \%$ & $39 \%$ \\
Large & $24 \%$ & $76 \%$ \\
\hline \hline
\end{tabular}

Source: World Business Environment Survey (WBES), 2001.

Note: "small" denotes small and medium firms up to 200 employees. "Large" firms have more than 200 employees. 
Table 2.3: Asymmetric Financing Opportunities

Dependent variable: Answer to the question "is financing a major obstacle to running your business?"

\begin{tabular}{|c|c|c|c|}
\hline & (1) & (2) & (3) \\
\hline $\mathrm{N}$-sector firms & $\begin{array}{c}0.175^{* * * *} \\
(0.039)\end{array}$ & & \\
\hline Share of exports & & $\begin{array}{c}-0.003^{* * *} \\
(0.001)\end{array}$ & \\
\hline NL & & & $\begin{array}{c}0.265^{* * *} * \\
(0.051)\end{array}$ \\
\hline NS & & & $\begin{array}{l}0.094^{*} \\
(0.053)\end{array}$ \\
\hline Age & & & $\begin{array}{l}-0.000 \\
(0.001)\end{array}$ \\
\hline Government share & & & $\begin{array}{c}-0.004 * * * \\
(0.001)\end{array}$ \\
\hline
\end{tabular}

Note: This table reports regression results of ordered probit regressions, specified with a constant and with country dummies. The answer to the question "is financing a major obstacle to running your business?" is evaluated on a scale from 1 to 4 . The independent variable in regressions 1 and 3 is a dummy that is equal to one for $\mathrm{N}$ sector firms and zero otherwise. In regression 2 , it is the share of exports among T-sector firms. In regression $3, \mathrm{NL}=$ Non tradable and large, NS $=$ Non tradable and small, the age of the firm, and the share of government participation. Standard errors are reported in parentheses; * indicates significance at the 10 percent level, ** indicates significance at the 5 percent level and $* * *$ indicates significance at the 1 percent level.

of table 2.1 is also exhibited by most MICs individually. ${ }^{4}$

The survey also asked firms to rank, on a scale from 1 to 4 , how much of an obstacle financing was to running their business. We use the answers from this survey to estimate an ordered probit model to assess whether there exists an asymmetry in financing opportunities across the $\mathrm{N}$ and T-sectors. ${ }^{5}$

We create a dummy variable for the yes-or-no answer "do you export?" A significant positive parameter on the dummy indicates that $\mathrm{N}$-sector firms evaluate the access to finance

\footnotetext{
${ }^{4}$ There are some large firms in the N-sector, such as utilities. However, in most countries they represent a small share of the $\mathrm{N}$-sector firms in the survey.

${ }^{5}$ We use the same approach as Schiffer and Weder (2001), who compare small and large firms with respect to financing constraints as well as other indicators of governance. They find that small firms are more constrained.
} 
as a significantly larger obstacle to running their business than do T-sector firms. We estimate ordered probit regressions of the following form.

$$
\begin{aligned}
y_{i}^{*}= & \beta_{0}+\beta_{1} \text { EXPORT }+\beta_{2} A G E+\beta_{3} G O V+\gamma_{1} d_{1 i}+\ldots+\gamma_{n} d_{n i}+\varepsilon_{i}, \\
\text { where } y_{i}= & \left\{\begin{array}{ccc}
1 & \text { if } & y_{i}^{*}<\alpha_{1} \\
2 & \text { if } & \alpha_{1}<y_{i}^{*}<\alpha_{2} \\
3 & \text { if } & \alpha_{2}<y_{i}^{*}<\alpha_{3} \\
4 & \text { if } & \alpha_{4}<y_{i}^{*}
\end{array}\right\}
\end{aligned}
$$

$\mathrm{n}=27$, and EXPORT is either a dummy that takes the value of 1 if the firm does not export, or it is the share of exports in output among exporting firms. $G O V$ controls for government participation in the firm, $A G E$ denotes the year a firm was established and $d_{1} \ldots d_{n}$ are country dummies. The dependent variable, $y$, captures the ranking of the severity of an obstacle for running a business, as perceived by the firms. The obstacles considered are financing, collateral and the exchange rate. The true y is not directly observed, and the $\alpha$ parameters are estimated together with $\beta_{0} \ldots \beta_{3}$ and $\gamma_{1} \ldots \gamma_{n}$

Table 2.3 reports the regression results: regression 1 is the basic regression where we regress the perceived credit constraints on the N-sector dummy. Regression 2 replaces the N-Sector by a variable that measures the percentage of output that is exported by exporters. Regression 3 reports the results of a regression that differentiates between small and large N-firms, and includes the age of the firm and the share of government participation as control variables. 
Table 2.4: The Use of Collateral in Securing Loans

\begin{tabular}{lc}
\hline \hline Indonesia & $50-60 \%$ \\
Korea & $90 \%$ \\
Malaysia & $40 \%$ \\
Philipines & $50-60 \%$ \\
Thailand & $50-60 \%$ \\
\hline \hline
\end{tabular}

Source: Dwor-Frecaut, D, M. HallwardDriemeier, F.X. Colaço, Asian Corporates' Credit need and Goverance, Presented at the 1999 World Bank Conference in Bankok.

In all regressions we find that there is a significant difference between exporters and nonexporters in their evaluation of financing as an obstacle to running their businesses. The latter consider the obstacle to be more severe. Furthermore, we find that among exporters, the larger the share of exports in output, the less significant is financing deemed to be as an obstacle for running a business. We also find that older firms have easier access to financing than younger firms. The same is true for firms with high government participation. None of the control variables, however, obviates the role of the exporters/non-exporters indicator.

Next, we ask whether bank credit depends on collateral and whether there is a statistically significant difference between the $\mathrm{N}$ - and T-sectors in this respect. Tables 2.4 and 2.5 shed light on this question. Table 2.4 shows that in most MICs, the majority of bank loans are indeed secured by collateral. The percentage ranges from $40 \%$ in Malaysia to $90 \%$ in Korea. In Table 2.5 we make use again of the WBES data set, where firms were also asked to evaluate how much of an obstacle the access to collateral is to running their business. Table 2.5 shows that even after controlling for other factors, such as government share and the age of the firm, the importance of collateral is viewed as significantly more severe by the firms 
Table 2.5: The Role of Collateral as an Obstacle to Obtain Financing

Dependent variable: the answer to the question:

"Is collateral a major obstacle to obtain financing?"

\begin{tabular}{|c|c|c|c|}
\hline & $(1)$ & (2) & (3) \\
\hline N-sector firms & $\begin{array}{c}0.127 * * * \\
(0.039)\end{array}$ & & \\
\hline Share of exports & & $\begin{array}{c}-0.0005^{*} \\
(0.008)\end{array}$ & \\
\hline NL & & & $\begin{array}{l}0.118^{*} \\
(0.052)\end{array}$ \\
\hline NS & & & $\begin{array}{l}0.034^{*} \\
(0.055)\end{array}$ \\
\hline Age & & & $\begin{array}{l}-0.004 \\
(0.001)\end{array}$ \\
\hline Government share & & & $\begin{array}{l}-0.001 \\
(0.001) \\
\end{array}$ \\
\hline
\end{tabular}

Note: Table 4 reports regression results of ordered probit regressions, specified with a constant and with country dummies. The answer to the question, "Is collateral a major obstacle to obtain financing?" is evaluated on a scale from 1 to 4. The independent variable in Regression 1 is a dummy that is equal to one for $\mathrm{N}$ sector firms and zero otherwise. In Regression 2, it is the share of exports among T-sector firms. In Regression 3, NL = Non tradable and large, NS = Non tradable and small, the age of the firm, and the share of government participation. Standard errors are reported in parentheses. * indicates significance at the 10 percent level, $* *$ indicates significance at the 5 percent level and $* * *$ indicates significance at the 1 percent level. 
Table 2.6: Structure of Cooperate Financing in Korea

\begin{tabular}{lccr}
\hline \hline & 1997 & 1998 & \multicolumn{2}{c}{1999} \\
\cline { 2 - 4 } Borrowing from Domestic & Money & Banks \\
large & 25.1 & 29.6 & 28.1 \\
SME & 74.8 & 70.3 & 71.8 \\
Gross issuance of cooperate bonds & \\
large & 90.8 & 99.1 & 94.3 \\
SME & 9.2 & 0.9 & 5.7 \\
\hline \hline
\end{tabular}

Source: IMF country Report 00/10

in the N-sector than those in the T-sector.

Aside from easier access to bank credit, firms in the T-sector are typically large firms that have the possibility to issue bonds and stocks as substitutes for bank credit. Figure 2.6 illustrates this for the case of Korea. While small and medium enterprises account for about $75 \%$ of domestic bank credit, more than 90 percent of domestic bonds were issued by large firms.

\subsection{Currency Mismatch and Banks Exposure to the N-sector}

Currency mismatch exists when liabilities are denominated in foreign currency, while the income streams that must service these debts are denominated in domestic currency. Currency mismatch has become an important issue in MICs because sudden real depreciations increase significantly the debt burden of a large group of agents, generating a meltdown of the banking system.

Unfortunately, there are no readily available indices of currency mismatch, so the question arises as to how best to measure this concept. First of all, currency mismatch need not be a problem that affects the aggregate economy. It is a sectorial problem that mainly affects the 
Table 2.7: Bank Lending by Sector

\begin{tabular}{lcr}
\hline \hline & \multicolumn{2}{c}{ Assets } \\
\cline { 2 - 3 } & $\begin{array}{l}\text { Loans to Non- } \\
\text { tradables }\end{array}$ & $\begin{array}{l}\text { Loans to } \\
\text { Tradables }^{2}\end{array}$ \\
\cline { 2 - 3 } Argentina (95) & $67.1^{3}$ & 32.9 \\
Chile (85) & 60.1 & 39.9 \\
Korea (97) & $74.8^{5}$ & 25.1 \\
Mexico (95) & 66.0 & 33.9 \\
Peru (96) & 59.2 & 40.8 \\
Thailand (97) & 66.5 & 34.5 \\
Turkey (93) & $34.0^{4}$ & $66.0^{4}$ \\
\hline \hline
\end{tabular}

Sources: See Appendix.

Notes: 1) N-Sectors: Construction, Real Estate Business, Infrastructure, Services, Personal Consumption, Commerce, Wholesale and Retail, Housing, Electricity-Gas-Water, Restaurants, Hotels, Transportation, Small. 2) T- Sectors: Mining, Quarrying, Industry, Agriculture, Forestry; Industrial Sector, Foreign Entities, Primary Production, Imports, Trade, Large, Other. 3) not including consumption or Housing credit. 4) only consumption credit is N. 5) N is proxied by small, T is proxied by large firms.

$\mathrm{N}$-sector. It may well be the case that there is enough foreign currency available to service the debt. However, if $\mathrm{N}$-sector debtors and the banks that lend to them have currency mismatch, then a real depreciation might generate a meltdown, unless the government can implement a redistribution from the $\mathrm{T}$ to the $\mathrm{N}$-sector on short notice. Clearly, these fiscal transfers are not feasible.

Since in MICs banks are heavily exposed to the N-sector, we can get a more precise indicator of currency mismatch by looking at the balance sheet of the banking system. Table 2.7 shows that, on average, only about a third of bank lending goes to firms that can potentially be classified as belonging to the tradeable sector. This indicates that the banking system is strongly exposed to the N-sector. ${ }^{6}$

\footnotetext{
${ }^{6}$ In order to bias the results against the hypothesis that banks are heavily exposed to the N-sector,
} 
Table 2.8: Share of foreign currency liabilities covered by income from exports

\begin{tabular}{lccccc}
\hline \hline & Liabilities & Assets & \multicolumn{2}{c}{$\begin{array}{c}\text { Foreign currency } \\
\text { coverage of assets }\end{array}$} & $\begin{array}{c}\text { Currency } \\
\text { Mismatch }\end{array}$ \\
\cline { 2 - 6 } & $\begin{array}{c}\text { (a) } \\
\text { \% of foreign } \\
\text { currency } \\
\text { liabilities }\end{array}$ & $\begin{array}{c}\text { (b) } \\
\text { Loans to } \\
\text { Tradables }\end{array}$ & $\begin{array}{c}(\mathrm{c}) \\
\text { Export/ } \\
\text { output }\end{array}$ & $\begin{array}{c}(\mathrm{d}) \\
(\mathrm{b})^{*}(\mathrm{c})\end{array}$ & $\begin{array}{c}(\mathrm{e}) \\
(\mathrm{a}) /(\mathrm{d}), \\
\left(\text { lower bound }{ }^{3}\right)\end{array}$ \\
\cline { 2 - 6 } Argentina (95) & 35.0 & 32.9 & 0.30 & 9.8 & 3.57 \\
Chile (83) & 46.7 & 39.9 & 0.28 & 11.2 & 4.17 \\
Korea (97) & $17.9^{1}$ & 25.1 & 0.34 & 8.53 & 2.97 \\
Mexico (95) & 33.4 & 33.9 & 0.23 & 7.7 & 4.34 \\
Peru (96) & 73.0 & 59.2 & 0.34 & 20.1 & 3.62 \\
Thailand (97) & 22.3 & 34.5 & 0.17 & 5.8 & 3.85 \\
Turkey (93) & 47.0 & 66.0 & 0.24 & 15.84 & 2.97 \\
\hline \hline
\end{tabular}

Source: See Appendix.

Note. 1) Data on loans in Chile are 1985. 2) Foreign liabilities data in Korea is from 1993 thus the mismatch in 97 must have been much larger. 3) The results are biased against finding our hypothesis of currency mismatch in several important ways: 1) Off balance sheet items are not included, which are primarily in foreign currency. 2)Due to legislation banks tend to underreport their foreign currency holdings as a share of liabilities (see Kamin et. al 2001). 3) We assume that all revenues from exports can be used to service the debt. All firms in potentially tradable sectors are assumed to indeed be tradeable.

Since banks are strongly exposed to the N-sector we cannot determine the degree of currency mismatch by simply comparing the liabilities and the assets of the banking system. A bank can have $20 \%$ of its liabilities in dollars and $20 \%$ of its assets denominated in dollars. However, if all the loans are granted to the N-sector, there is a de facto currency mismatch because there is insolvency risk. It may be even more misleading just to compare the denomination of deposits and loans, as these are only a subset, and a small subset at that, of the total balance sheet. ${ }^{7}$

we assume that all firms in sectors that are commonly considered tradable are indeed tradable. Thus, we group manufacturing, mining, agriculture, forestry, and primary production as tradables, while construction, services, electricity-gas-water are considered nontradables. Note that the fraction of bank lending that goes to consumption or housing credit is not covered by foreign currency income and thus also counts as nontradable. In most countries, the figures would be even higher if these items were included (consumption and housing credit are only available for Hungary, Mexico and Thailand).

${ }^{7}$ For instance, foreign currency deposits in Thailand account for less than $10 \%$ of the total foreign external liabilities of the banking system. 
Table 2.9: Aggregate indicators of currency mismatch

\begin{tabular}{|c|c|c|}
\hline & $\begin{array}{l}\text { Foreign debt Service/ } \\
\text { Exports }\end{array}$ & Foreign debt/ Exports \\
\hline Argentina & 0.37 & 4.73 \\
\hline Chile & 0.26 & 2.13 \\
\hline Korea & 0.09 & 0.76 \\
\hline Mexico & 0.36 & 2.30 \\
\hline Peru & 0.25 & 5.77 \\
\hline Thailand & 0.18 & 1.47 \\
\hline Turkey & 0.56 & 3.60 \\
\hline
\end{tabular}

Source: World Bank Development indicators (year: 1994)

Our index of currency mismatch compares the share of foreign currency liabilities of the banking system to the share of loans that are covered by export income. We compute the latter ratio by multiplying the share of bank lending that goes to the T-sector by the share of T-sector output that is actually exported. Column (c) in Table 2.8 shows that exporting firms sell the majority of their output in the domestic market. Thus, they too must earmark a large share of domestic currency revenue for servicing foreign currency debt.

Our index of currency mismatch is reported in column (e) of Table 2.8. The estimates range from 2.97 for Korea in 1997 to 4.34 for Mexico in $1995 .^{8}$ To see that currency mismatch is mostly a sectorial, not an aggregate, problem compare Table 2.8 with Table 2.9. Notice that the foreign debt service-to-exports ratio is low in countries with a high currency mismatch index. A banking system where only 15-30\% of dollar loans are covered by exports are certainly subject to substantial real exchange rate risk. This is true even though the aggregate measures of Table 2.9 do not indicate currency mismatch. ${ }^{9}$

\footnotetext{
${ }^{8}$ Our estimates of CM are conservative. More realistic/accurate estimates would take into account that the amount of foreign currency revenue that is available to service debt is less than total foreign currency income. Some of the foreign currency income is required to pay off the factors of production.

${ }^{9} \mathrm{~A}$ high foreign debt service-to-exports ratio signals a CM problem. However, just because this aggregate
} 


\subsection{Systemic Guarantees}

Despite the fact that bailout guarantees have played an important role in several explanations of boom-bust cycles, the evidence supporting the existence of this distortion is mainly anecdotal. Although many countries have systemic guarantees in place, it is very difficult to document their existence directly. The difficulty in pinning guarantees down is that in most cases they are implicit. To begin with, they are not limited to promises to hand out a bailout payment to lenders in case of default. They are often implicit in the exchange rate regime and monetary policy rules. Since in most instances one of the objectives of policymakers is to avoid sharp drops in output, they will implement policies that are, de facto, implicit guarantees against systemic crises. ${ }^{10}$

We investigate whether there are implicit guarantees by looking at the behavior of interest rate spreads. The idea is that if guarantees are present, the spread will, ceteris paribus, be insensitive to a deterioration in the average quality of loans, assuming, of course, that no crisis has yet occurred. When a crisis occurs, the quality of loans collapses and the spread skyrockets.

An ideal way to measure the evolution of the loans' quality is with the 'true' share of non-performing loans (NPLs). Unfortunately, such data in time series form does not exist for most MICs. A good proxy for an increase in NPLs is the occurrence of a lending boom in the recent past. When there is a sharp acceleration in credit, the monitoring capacity

\footnotetext{
measure may be low, one cannot infer that there is no CM.

${ }^{10}$ Systemic guarantees are not the same as deposit insurance schemes, which cover individual agents against idiosyncratic risk.
} 
of both banks and regulators is diminished, so that there is an increase in the likelihood of granting credit to bad projects. The increase in the share of NPLs may take some time to materialize because it takes time for a given loan to become non-performing and because during the boom a lot of new loans are being granted. Nonetheless, after some time NPLs must become a problem for the banking system. This is true regardless of whether NPLs are officially recorded.

To capture this idea we run the following panel regression

$$
(\rho-r)_{j, t}=\alpha_{j}+\alpha_{1} L B_{j, t-1}+\alpha_{2} D_{j, t} \cdot L B_{j, t-1}+\varepsilon_{j, t}
$$

where $(\rho-r)_{j, t}$ is the interest rate spread as defined earlier, in country $j$ at time $t . L B_{j, t-1}$ is a dummy that indicates the existence of a lending boom. It is equal to one if during the past 2 years real credit has grown by more than $10 \%$ on average. $D_{j, t}$ is a dummy that indicates that twin banking and currency crises have occurred at $t$ or $t-1$.

The coefficient $\alpha_{1}$ measures the effect of an increase in NPLs on the spread in countryyears in which a crisis has not occurred in either the current or the previous year. Meanwhile, the sum $\alpha_{1}+\alpha_{2}$ measures the effect of an increase in NPLs on the spread during crisis times (at $t$ or $t-1$ ). As we discussed above, in order to isolate the effect of guarantees we need to distinguish between periods in which a crisis has not occurred recently, and periods where a crisis has occurred recently. This is because systemic crises are typically preceded by lending booms and during crises the spread shoots up.

The null hypothesis that there are systemic guarantees is $H_{0}: \alpha_{1}=0$. Table 2.10 exhibits 
Table 2.10: Implicit Bailout Guarantees

Dependent variable: Interest rate spread

\begin{tabular}{lcccc}
\hline \hline & \multicolumn{2}{c}{ (a) MIC 8 } & \multicolumn{2}{c}{ (b) Group of 39 } \\
\cline { 2 - 5 }$L B_{\mathrm{j}, \mathrm{t}-1}$ & $(1)$ & $(2)$ & $(3)$ & $(4)$ \\
\cline { 2 - 5 }$D_{\mathrm{j}, \mathrm{t}}{ }^{*} L B_{\mathrm{j}, \mathrm{t}-1}$ & $2.559^{* * *}$ & 1.330 & $0.723^{* *}$ & -0.188 \\
& $(0.930)$ & $(0.875)$ & $(0.348)$ & $(0.485)$ \\
$\mathrm{Adj} . \mathrm{R}^{2}$ & & $3.849^{* * *}$ & & $2.833^{* * *}$ \\
$\mathrm{~N}$ & 0.531 & $(1.131)$ & & $(1.007)$ \\
\hline \hline
\end{tabular}

Note: The table shows the estimates of the panel regression in (5.1). The lending boom dummy, $L B$, is equal to one, if the growth rate of real credit has been larger than 10 percent on average for the past two years. The crisis dummy, $D$, indicates that a twin crisis occurred in $t$ or $t+1$. The regressions are estimated with fixed effects, using a GLS estimator. Standard errors are reported in parentheses; * indicates significance at the 10 percent level, ** indicates significance at the 5 percent level and $* * *$ indicates significance at the 1 percent level.

the estimates of regression (2.1). Panel (a) considers a set of 8 MICs frequently discussed in the literature, while panel (b) considers the full set of 39 MICs. In both cases we cannot reject the null at the $10 \%$ significance level. That is, we cannot reject the presence of systemic guarantees. Interestingly, if the crisis dummy is disregarded and the spread is regressed only on the lending boom dummy, the estimated coefficient is statistically significant at the $10 \%$ level.

If we were to define systemic guarantees literally as promises to hand out a bailout payment to lenders in case of default, we could investigate the proportion of crises that have triggered this type of bailouts, and then impose rational expectations to infer the exante implicit guarantee. Bordo and Schwarz (2001) and Jeanne and Zettelmeyer (2000) find evidence of ex-post bailouts during the last two decades and the early banking crises of the 20 th century. 


\section{Macroeconomic Patterns}

The credit market imperfections we have documented give rise to macroeconomic patterns that are common across MICs, but are not typically observed in high income countries. In this section we illustrate these patterns both by examining the comovements of the relevant variables conditioning on the occurrence of twin crises, and by characterizing the unconditional comovements of these variables. In the next section we describe the mechanism that links the credit market imperfections to the macroeconomic patterns.

We characterize the boom-bust cycle by means of event windows over the period 19801999 on the set of 39 MICs where, in addition to banks, the stock market is a viable source of finance. Figure 3.1 shows that prior to a crisis there is a real appreciation and a lending boom during which credit grows unusually fast. In the aftermath of a crisis there is typically a short-lived recession and a protracted credit crunch that affects mainly the N-sector. In fact, N-production declines relative to the output of the T-sector and the credit-to-GDP ratio continues to fall for several years after the crisis. Investment is the component of GDP that exhibits by far the largest (and statistically significant) deviations from tranquil times, while consumption deviations are very mild and insignificant. ${ }^{11}$

We characterize the unconditional comovements by means of panel regressions over the same period and set of countries. In the panel regressions, we allow for random and fixed effects. ${ }^{12}$ The partial correlations cannot, of course, be interpreted as causal relations. How-

\footnotetext{
${ }^{11}$ Figure 3.1 is taken from Tornell and Westerman (2002a). See that paper for details.

${ }^{12}$ All variables are in first differences in order to avoid the issues associated with non-stationarity. These patterns have been characterized by Tornell and Westermann (2002b).
} 
Figure 3.1: The Boom-Bust Cycle

a) Real Appreciation

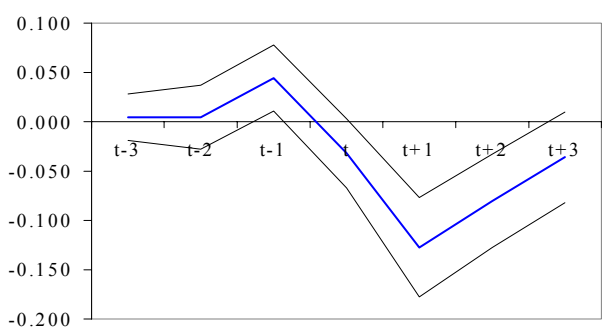

c) N-to-T Output Ratio

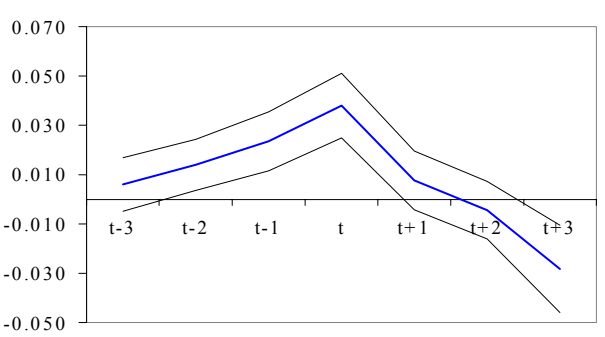

e) Investment/GDP

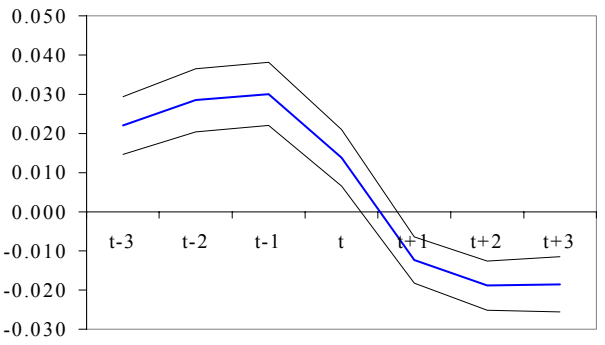

b) Credit/GDP

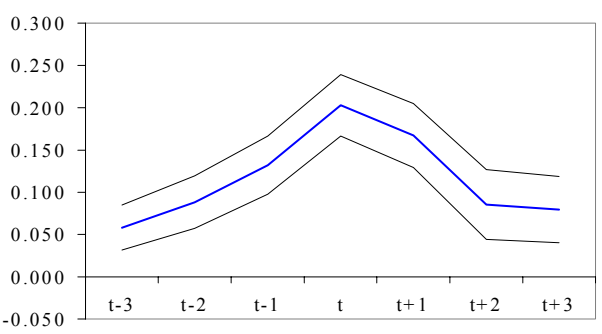

d) Interest Rate Spread

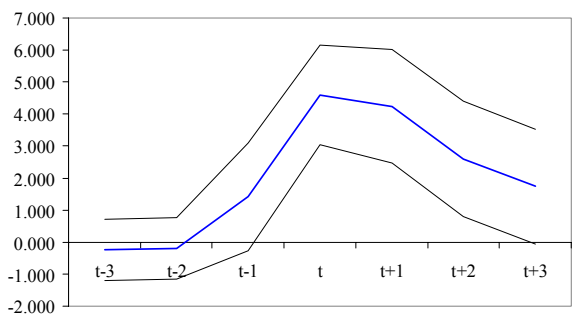

f) Consumption/GDP

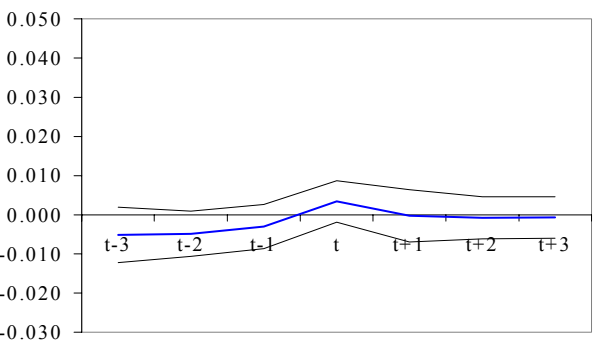

Note: The figures show the average behavior of the respective variable, across 39 countries around twin currency and banking crises during the period 1980-1999. Index $t$ in the figures refers to the year during which a twin crisis takes place. The figures are the visual representations of the point estimates and standard errors from regressions in which the respective variable in the graph is the dependent variable, regressed on time dummies preceding and following a crisis. The panel data estimations include fixed effects and use a GLS estimator. The heavy line represents the average deviation relative to tranquil times. The thin lines represent the $95 \%$ confidence interval. 
Table 3.1: Random Effects Model

Dependent Variable: Real Credit Growth

\begin{tabular}{lcccc}
\hline \hline & $(1)$ & $(2)$ & $(3)$ & $(4)$ \\
\cline { 2 - 5 } 1/Real exchange rate & $0.370^{* * *}$ & $0.356^{* * *}$ & $0.212^{*}$ & $0.216^{* *}$ \\
& $(0.074)$ & $(0.089)$ & $(0.112)$ & $(0.106)$ \\
N/T output ratio & $0.294^{* * *}$ & $0.387^{* * *}$ & $0.241^{*}$ & $0.290^{* *}$ \\
& $(0.109)$ & $(0.127)$ & $(0.139)$ & $(0.137)$ \\
Interest rate spread & & $-0.002^{* *}$ & $-0.071^{* * *}$ & $-0.063^{* * *}$ \\
& & $(0.001)$ & $(0.021)$ & $(0.020)$ \\
Investment & & $0.306^{* * *}$ & $0.219^{* * *}$ \\
& & & $(0.107)$ & $(0.078)$ \\
Consumption & & -0.228 & \\
& & & $(0.263)$ & \\
Deficit & & & $0.614^{* *}$ & $0.591^{* *}$ \\
& & & $0.249)$ & $(0.259)$ \\
Net exports & & & 0.000 & \\
& & & $0.001)$ & \\
Adj. $\mathrm{R}^{2}$ & 0.211 & 0.180 & 0.363 & 0.376 \\
\# countries & 30 & 26 & 25 & 25 \\
\hline \hline
\end{tabular}

Note:. The table reports the regression results from a model with random effects. Standard errors are reported in parentheses; $*$ indicates significance at the 10 percent level, ** indicates significance at the 5 percent level and $* * *$ indicates significance at the 1 percent level.

ever, they indicate the variables that theoretical models should emphasize.

The first regression in Table 3.1 shows that an increase in credit is associated with (i) a decline in the interest rate spread, (ii) an increase in the ratio of N-to-T output, and (iii) a real appreciation. It is remarkable that these partial correlations are significant at the $1 \%$ level. Correlation (i) suggests the existence of a credit channel. Correlation (ii) is consistent with the fact that the N-sector is more credit-constrained than the T-sector. Correlation (iii) is consistent with the existence of a balance sheet effect. ${ }^{13}$

Among components of GDP, what is surprising is the dog that didn't bark: consumption and net exports do not move with credit growth. In contrast, investment and the fiscal deficit

\footnotetext{
${ }^{13}$ The MICs we examine have experienced crises from time to time during the sample period. We are not limiting ourselves to analyzing the events surrounding crises, and the comovements of Tables 3.1 and 3.2 are not conditional on the occurrence of crises.
} 
Table 3.2: Fixed Effects Model

Dependent Variable: Real Credit Growth

\begin{tabular}{lcccc}
\hline \hline & $(1)$ & $(2)$ & $(3)$ & $(4)$ \\
\cline { 2 - 5 } 1/Real exchange rate & $0.398^{* * *}$ & $0.374^{* * *}$ & $0.258^{* *}$ & $0.234^{* *}$ \\
& $(0.081)$ & $(0.053)$ & $(0.119)$ & $(0.113)$ \\
N/T output ratio & $0.273^{* * *}$ & $0.295^{* * *}$ & 0.198 & $0.283^{*}$ \\
& $(0.081)$ & $(0.040)$ & $(0.151)$ & $(0.146)$ \\
Interest rate spread & & -0.002 & $-0.073^{* * *}$ & $-0.064^{* * *}$ \\
& & $(0.001)$ & $(0.022)$ & $(0.021)$ \\
Investment & & $0.324^{* * *}$ & $0.203^{* *}$ \\
& & & $(0.112)$ & $(0.083)$ \\
Consumption & & -0.390 & \\
& & & $(0.282)$ & \\
Deficit & & & $0.617^{* *}$ & $0.583^{* *}$ \\
& & & $0.295)$ & $(0.294)$ \\
Net exports & & 0.000 & \\
& & & $(0.001)$ & \\
Adj. $\mathrm{R}^{2}$ & 0.155 & 0.143 & 0.317 & 0.376 \\
\# countries & 30 & 26 & 25 & 25 \\
\hline \hline
\end{tabular}

Note:. GLS regression results from a model with fixed effects. Standard errors are reported in parentheses; * indicates significance at the 10 percent level, ** indicates significance at the 5 percent level and *** indicates significance at the 1 percent level.

vary strongly with credit. Regressions 2 and 3 show that all parameters, except those on consumption and net exports, are significant at the $5 \%$ level. We find similar results using fixed effects estimation (Table 3.2). After dropping insignificant variables, all remaining variables are significant at the $5 \%$ level and have the same sign as in the random effects model.

As we can see in Figure 3.1, macroeconomic variables display similar comovements as those shown in Tables 3.1 and 3.2. These stylized facts suggest that investment, rather than consumption, should play a key role in the amplification mechanism. Furthermore, they indicate that any model of macroeoconomic comovements or of crises in MICs should generate an equilibrium path along which credit varies negatively with the real exchange rate, and positively with the $\mathrm{N}$-to- $\mathrm{T}$ output ratio. 


\section{The Mechanism}

To explain some of the stylized facts that we have described, the literature has looked to financial market imperfections as key 'fundamentals'. Existing models are typically based on one of two distortions: either "bad policy", in the form of bailout guarantees, or "bad markets", in the form asymmetric information, or the imperfect enforceability of contracts in financial markets. ${ }^{14}$

On the one hand, policies that ensure agents against systemic crises (i.e., systemic bailout guarantees), lead agents to take on more risk than they otherwise would. This can explain risky debt denomination. On the other hand, credit market imperfections such as imperfect enforceability of contracts or asymmetric information lead lenders to be very conservative and give rise to credit constraints. The question arises as to whether one can construct an internally consistent framework where guarantees do not neutralize the credit market imperfections. Furthermore, can the interaction between these two distortions generate the dynamic patterns that characterize the boom-bust cycle and the comovements alluded to above?

Schneider and Tornell (2000) consider an economy where these two distortions do not neutralize each other and show how their interaction generates several features of the boom cycle. Tornell and Westermann (2002a and 2002b) show how this framework can explain the comovements alluded to above and the strong credit channel that exists in MICs.

\footnotetext{
${ }^{14}$ See for instance, Aghion, Bacchetta and Banerjee (2000), Burnside, Eichenbaum and Rebelo (2000), Caballero and Krishnamurthy (1999), Calvo (1998), Corsetti, Pesenti and Roubini (1999), Krugman (1999) and Mckinnon and Pill (1998).
} 
In what follows we discuss how some elements of these papers help explain the macroeconomic patterns we described in the previous section. Consider an economy with two sectors: a tradables sector $(\mathrm{T})$ and a nontradables sector $(\mathrm{N})$. T-sector agents have access to perfect capital markets, while N-sector agents face enforceability problems and systemic guarantees.

The first key result is that the interaction of systemic guarantees and enforceability problems generates a self-reinforcing mechanism. On the one hand, if there is sufficient real exchange rate risk: (a) binding credit constraints arise and (b) it is individually optimal for an $\mathrm{N}$-sector agent to issue debt denominated in T-goods (i.e., borrow in foreign currency on a short-term). On the other hand, when many $\mathrm{N}$-sector agents gamble by denominating their debt in $\mathrm{T}$ goods, exchange rate risk may be endogenously created, as the economy becomes vulnerable to self-fulfilling meltdowns of the banking system. If the amount of $\mathrm{T}$ denominated debt is high, a real depreciation can severely squeeze cash flow, or even bankrupt banks altogether. Since they face binding borrowing constraints, they then have to curtail lending to the N-sector. Weak investment demand from the N-sector for its own products in turn validates the real depreciation. The systemic credit risk created by the banking system thus induces endogenous exchange rate risk.

The second key result is that the interaction of binding borrowing constraints and $\mathrm{T}$ denominated debt generates a dynamic path that resembles a boom-bust cycle and the comovements we have characterized earlier. During the boom, the real appreciation reduces the debt burden and relaxes credit constraints, permitting unusually fast growth in the bank-dependent N-sector. This leads to further real appreciation, further relaxation of credit 
constraints and so on. Since the T-sector is not credit constrained, both the credit-to GDP and the N-to-T output ratios follow increasing paths. However, the existence of risky debt denomination makes the economy vulnerable to self-fulfilling twin crises, during which a real depreciation coincides with both a meltdown of the banking system and a collapse of the N-sector's internal funds. In the aftermath of crisis the N-sector is outperformed by the T-sector. Since banks are strongly exposed to the N-sector, a long-lasting credit crunch outlives a brief recession.

To understand the amplification mechanism in more detail consider an increase in the domestic lending rate. This shock leads to higher debt service obligations and thus implies that firms can now borrow less at each level of net worth. Lower borrowing results in lower investment. This direct effect is amplified because there is currency mismatch and part of N-sector's demand comes from the N-sector itself. In this case, the fall in demand for Ngoods, leads to a real depreciation. Since N-sector agents have dollar debt on the books, while their revenues are denominated in the local currency, there is a fall in N-sector's profits and net worth. A vicious circle ensues as lower net worth leads to even lower investment, which leads to a lower demand for N-goods and a steeper real depreciation, which leads to lower net worth and so on. This process might lead to twin crises in which a critical mass of $\mathrm{N}$-sector agents goes bust.

T-sector agents have access to international capital markets and can more easily substitute away from domestic borrowing. Thus, their decisions are mostly affected by the world interest rate, not by the domestic lending rate. Therefore, a fall in credit is associated with a 
real depreciation and a decline in the N-to-T output ratio. Furthermore, the sectorial asymmetry implies that the decline in GDP growth is milder than that of credit. This explains the persistent swings in the credit-to-GDP ratio observed in the data.

\section{Conclusions}

In this paper we have documented the existence of three credit markets imperfection prevalent in middle income countries (MICs). We have also discussed how they can account for macroeoconomic patterns observed across MICs in recent decades.

In MICs borrowing constraints affect many firms. However, their incidence is heavily biased towards the non-tradables $(\mathrm{N})$ sector. While tradables $(\mathrm{T})$ sector firms tend to be large and have access to world capital markets, N-sector firms are smaller on average and are bank-dependent.

A second imperfection is the substantial amount of $\mathrm{N}$-sector debt that is denominated in foreign currency, while the income streams that service those debts are in domestic currency. Since domestic banks are heavily exposed to the N-sector, the degree of currency mismatch is significant.

This sharp asymmetry in financial opportunities and the severe currency mismatch are key to understanding why there are sharp fluctuations in the real exchange rate (the relative price of $\mathrm{N}$ and $\mathrm{T}$ goods), and why they play a key role in the amplification and propagation of shocks in MICs.

The prevalence of currency mismatch does not appear out of the blue, but rather is the 
optimal response of borrowers and creditors to the existence of systemic guarantees, the third imperfection we have documented.

There is much work to be done in understanding economic fluctuations in MICs. This paper contributes to the literature by highlighting common macroeconomic regularities and by documenting the existence of three credit market imperfections that are prevalent in otherwise very different MICs. In so doing, we have restricted the classes of plausible explanations for economic fluctuations that are common across MICs. 


\section{References:}

Aghion, P., P. Bachetta, and A. Banerjee (2000), "Capital Markets and the Instability of Open Economies," mimeo, Study Center Gerzensee.

Bordo, M. and A. Schwartz (2001) "Measuring Real Economic Effects of Bailouts" NBER working paper 7701.

Burnside, C., M. Eichenbaum and S. Rebelo (2001), "Prospective Deficits and the Asian Currency Crisis," Journal of Political Economy, 109(6), 1155-97.

Caballero, R. and A. Krishnamurthy (2001), "International and Domestic Collateral Constraints in a Model of Emerging Market Crises," Journal of Monetary Economics, 48 (3), $513-48$.

Calvo, Guillermo (1998), "Capital Flows and Capital Market Crises: The Simple Economics of Sudden Stops," Journal of Applied Economics, pp 35-54.

Corsetti, G., P. Pesenti and N. Roubini (1999), "Paper Tigers: A Model of the Asian Crisis" European Economic Review 43(7), 1211-36.

Jeanne, O. and J. Zettelmeyer (2001), "International Bailouts, Moral Hazard and Coditionality," Economic Policy, October.

Krugman, Paul (1999), "Balance Sheets, The Transfer Problem, and Financial Crises," mimeo, MIT.

McKinnon, R. and H. Pill (1997), "Credible Economic Liberalizations and Overborrowing," American Economic Review 87(2), 189-93.

Schiffer, M. and B. Weder (2001), "Firm Size and the Business Environment: Worldwide 
Survey Results," IFC discussion paper 43.

Schneider, M. and A. Tornell (2000), "Balance Sheet Effects, Bailout Guarantees and Financial Crises," NBER working paper 8060.

Tornell, A. and F. Westermann (2002a), "Boom-Bust Cycles: Facts and Explanation", IMF Staff Papers (41), 111-165.

Tornell, A. and F. Westermann (2002b), "The Credit Channel in Middle Income Countries", NBER working paper 9355. 


\section{Appendix: Data Sources and Definitions}

\section{Panel regression.}

Source: World Bank Development Indicators (WBDI), IFS (IMF) and OECD Statistical Compendium.

Criteria for country selection:

We consider countries: a) that have a stock market and the value of the stocks traded as a share of GDP is larger than 1\%,b) that have a population of more than 1 million people, c) that have a per capita income of more than $\$ 1000$ but less than $\$ 18000$ and d)that are not engaged in war or civil war (Iran, Iraq, Yugoslavia and Lebanon). In addition, we consider Finland and Sweden. In total we have 39 countries. The sample covers 20 years, from 1980 to 1999. The panel is unbalanced, as not all series cover the full sample or are available for all countries.

Variables included in the regression:

Real credit growth: IMF, International financial Statistics, CD-ROM. Claims on private sector by deposit money banks (Lines 22d..ZF), divided by CPI (Lines 64..ZF); N/T: Services: World Bank Development indicators (Code: NV.SRV.TETC.KN), Manufacturing: World Bank Development indicators (Code: NV.IND.MANF.KN), Construction: OECD Statistical Compendium, Main indicators of industrial activity and individual central banks. See Tornell and Westermann (2002a) for selection criteria for N and T- Sectors; Interest rate spread: World Bank Development indicators (Code: FR.INR.LNDP); Real interest rate: World Bank Development indicators (Code: FR.INR.RINR); Gross domestic fixed investment: World 
Bank Development indicators (Code: NE.GDI.FTOT.KN); Private Consumption: World Bank Development indicators (Code: NE.CON.PRVT.KN)

2. Probit regressions.

Source: World Business Economic Survey (WBES).

Variables included in the regressions:

label var gcf "General constraint-financing" $1=$ no obstacle $4=$ major obstacle; label var exp_yn "Exports" 1=yes, 2=no; label var exp_pct "\% of output exported"; label var yr_estb "year established"; label var gvt_pct "Percent government ownership."

\section{Currency Mismatch:}

Sources: Bank of Argentina, Bank of Brazil, Bank of Korea, Bank of Peru, Bank of Turkey, BANXICO, Dirección General de Investigación Económica. Indicadores Económicos, May 1996 and 2001. Dziobek, Claudia, J. Kim Hobbs and David Marston, 2000, "Toward a Framework for Systemic Liquidity Policy," IMF Working Paper 00/34 (Washington: International Monetary Fund). Takatoshi Ito and Luiz A. Pereira da Silva: "The Credit Crunch in Thailand during the 1997-98 Crisis: Theoretical and operational issues with the JEXIM survey". Steven Kamin, Philip Turner and Jozef Van’t Dack*, "The transmission mechanism of monetary policy in emerging market economies: an overview", mimeo, BIS conference, OECD Bank Profitaility statisitics. 